\title{
O PENSAMENTO FREUDIANO SOBRE A INTOLERÂNCIA
}

\author{
Betty Bernardo Fuks*
}

\section{RESUMO}

A partir do conceito psicanalítico de "narcisismo das pequenas diferenças", o artigo tem como objetivos pensar o modo como Freud foi tecendo um pensamento sobre a intolerância e discutir as contribuiçóes da psicanálise à história das teorias sobre a tolerância. A autora perscruta o fenômeno de intolerância à diferença do outro à luz dos trabalhos de Freud que envolvem e atestam sua sensibilidade para com a intolerância racista que atingiu o tempo em que viveu. Desde este trajeto, propõe algumas definiçôes do termo tolerância - criado no século XVI durante as guerras religiosas entre católicos e protestantes - para o campo da psicanálise.

Palavras-chave: narcisismo das pequenas diferenças, intolerância, tolerância, racismo, nazismo

\section{AbSTRaCT}

\section{The Freudian ideas on INTOleranCE}

From the psychoanalytic concept of "narcissism of the small differences" the article's objective is to think how Freud elaborated some ideas on intolerance and to argue the role of psychoanalysis in the history of the theories on tolerance. The author investigates the intolerance to the difference of the other, under the light of Freudian work that involves and attests his sensitivity to the violence that was present during his lifetime. After this journey, she proposes some definitions for the term intolerance - created in the $16^{\text {th }}$ century during the religious wars between Catholics and Protestants - for the field of psychoanalysis.

Keywords: narcissism of the small differences, intolerance, tolerance, racism, nazism

* Psicanalista; Professora do Mestrado em Psicanálise, Saúde Mental e Sociedade da Universidade Veiga de Almeida; Psicanalista. 
No decorrer das guerras religiosas do século XVI, a urgência de estabelecer parâmetros mínimos de convivência entre católicos e protestantes determinou a criação do termo tolerância (e correlativamente o de intolerância). Aos poucos, a hostilidade da fé começa a ceder espaço à experiência do viver mais de acordo com os sentidos da palavra tolerância - respeito pela opinião de outrem, delicadeza e cuidado para com o outro e consideração à liberdade de pensamento e da fé. Nos séculos seguintes, dedicando-se a pensar a questão da intolerância, sempre residual e ameaçadora, livres-pensadores e filósofos cunharam o conceito de tolerância, em torno do qual se produziram teorias. Durante o Iluminismo, o radicalismo anti-religioso instalado entre muitos marcou uma passagem negra na história das teorias da tolerância. Para enfrentar a intolerância da fé, assim como o obscurantismo doutrinal e político que se opunha ao "progresso das luzes", isto é, "à difusão em todas as classes sociais dos conhecimentos científicos e da atitude racionalista que elas exigem" (Lalande, 1993: 756), a tolerância da razão endurece os propósitos de fazer desaparecer todas as formas substanciais de crença (Wismann, 2000). O pensamento da tolerância produziu, então, uma espécie de "religião da razão", criando uma contradição no seio da filosofia: a intolerância da tolerância. Contra este estado de coisas, surge um novo modo de pensar: no século XIX, Goethe alerta para o fato de que a tolerância seria apenas uma atitude transitória que deve levar ao reconhecimento do outro. "Tolerar é injurioso", dizia o poeta (Goethe, citado por Wismann, 2000: 100). A idéia de reconhecimento do outro, no que força o pensamento a absorver o entendimento da alteridade, obriga a tomada de uma posição ética capaz de fazer frente à violência do racismo, da xenofobia e do sexismo e outras formas hodiernas da intolerância do mesmo.

No início do século XX, na mesma velha Europa das guerras religiosas, a intolerância ao outro, desta vez balizada pelo cientificismo da raça, começa a fazer o ruído que terminou emudecendo milhares de seres humanos em campos de extermínio. Sabe-se que Freud funda a psicanálise no início daquele século e que o desenvolvimento de sua teoria ocorreu durante a ascensão da ideologia que sustentava o sonho da luta das raças pela dominação do mundo - o nazismo. $\mathrm{O}$ termo intolerância, advindo da filosofia, não é propriamente um conceito psicanalítico, o que não nos impede de formular algumas questões: de que modo Freud inseriu sua disciplina na luta contra os fenômenos de hostilidade ao outro que testemunhou e que ferramentas teóricas construiu para decifrá-los? Como pensar psicanaliticamente o ressurgimento histórico da intolerância nos dias atuais, cada vez mais submergidos no processo de alteração do horror que Hannah Arendt (1979) chamou de "banalização do mal"? 


\section{NARCISISMO DAS PEQUENAS DIFERENÇAS E INTOLERÂNCIA AO OUTRO}

Comecemos por uma citação.

Toda vez que o homem primitivo tem de estabelecer um tabu, ele teme algum perigo e não se pode contestar que um receio generalizado das mulheres se expressa em todas essas regras de evitar. Talvez este receio se baseie no fato de que a mulher é diferente do homem, eternamente incompreensível e misteriosa, estranha e, portanto, aparentemente hostil. O homem teme ser enfraquecido pela mulher, contaminado por sua feminilidade e, então, mostrar-se ele próprio incapaz $[. .$.$] . Em tudo isso não há nada obsoleto, nada que não perma-$ neça ainda vivo em nós mesmos.

Utilizando expressões que diferem apenas ligeiramente da terminologia habitual da psicanálise, Crawey, [num estudo sobre o homem primitivo], assinala que cada indivíduo se separa dos demais por um "tabu de isolamento pessoal" e que justamente em suas pequenas diferenças, não obstante a semelhança quanto a todo o resto, se fundamentam os sentimentos de estranheza e hostilidade entre eles. Seria tentador desenvolver essa idéia e derivar desse "narcisismo das pequenas diferenças" a hostilidade que, em todos os vínculos humanos, observamos lutar com êxito contra os sentimentos de solidariedade e sobrepujar o mandamento de amar ao seu próximo. A psicanálise acredita que descobriu grande parte do que fundamenta a rejeição narcísica que os homens voltam às mulheres, ao chamar a atenção para o complexo de castração e sua influência sobre a opinião, baseada no desprezo, em que são tidas as mulheres (Freud, [1918] 1976: 193).

Esta passagem figura em "O tabu da virgindade" (Freud, [1918] 1976). Poderia ter escolhido qualquer outro escrito das Obras completas como intróito ao tema proposto no título. Tal justificativa baseia-se no fato de que a descoberta freudiana tem como fundamento enfrentar a inquietação do outro enquanto malestar, a partir da permanência de uma “outra cena” em nós - o Inconsciente. Entretanto, a escolha do texto de 1918 obedece às seguintes razões:

1) pelo fato de ser a primeira vez que Freud refere-se à noção de "narcisismo das pequenas diferenças". Em termos normais, o "narcisismo das pequenas diferenças" está na base da constituição do "eu", do "nós" e do outro, na fronteira que tem por função resguardar o narcisismo da unidade. Quando levado ao paroxismo, desemboca na segregação e no racismo, expressões máximas da intolerância ao outro e tolerância ao mesmo. Da hostilidade à mulher a todos estes fenômenos, Freud utilizou a noção de narcisismo das pequenas diferenças para refletir sobre o 
par de opostos tolerância/intolerância, no plano individual e coletivo. Foi com esta ferramenta conceitual que a psicanálise, diante do fenômeno de manipulação do sentimento de estranheza à diferença do outro que explodiu no interior das grandes massas modernas, se voltou para o campo da política. Ainda que raramente o termo política apareça designado como tal em sua obra, "Psicologia das massas e análise do eu” (Freud, [1921] 1976), "Mal-estar na cultura” (Freud, [1930] 1976) e "Moisés e o monoteísmo" (Freud, [1939] 1976) testemunham as inquietações de Freud para com a violenta manipulação do fenômeno de intolerância ao outro pelo poder. E finalmente, em "Porque a guerra" (Freud, [1933] 1976), ao discutir com Albert Einstein a possibilidade da paz mundial, assume preferir substituir a palavra "poder" por "violência".

2) pela transparência do texto no que concerne ao modo como Freud analisa os acontecimentos de seu tempo, reconhecendo o passado e o presente como cenas conjugadas uma à outra, fora do regime de mútua exclusão e articulando entre si passagens complexas. Entre a escuta clínica e os estudos etnológicos sobre a vida dos selvagens, a escrita de Freud torna-se provocante. Há algo no homem moderno pelo qual ele não consegue se identificar plenamente com a emancipação da mulher ocorrida no decurso do século XIX: um resto pulsional não dominado, isto é, não absorvido pelas malhas da cultura. Portanto, a arte que permitiu a Freud construir uma teoria crítica da cultura foi a de ter se confrontado com a evidência da tensão entre o que pertence à ordem do intemporal - a vida, a morte, as pulsões e as paixões avassaladoras - e o que é da ordem da história de sua época, as incidências sociais e políticas que, inevitavelmente, atingem também o discurso psicanalítico.

Resumindo: o liame entre "O tabu da virgindade" (Freud, [1918] 1976) e os textos freudianos cujo foco de interesse maior são os fenômenos sociopolíticos na civilização é o tema da intolerância à diferença do outro. Veremos de que modo esta expressão verbal se concretizou violentamente no contexto histórico dos anos $30 \mathrm{e}$ que efeitos provocou sobre um pensamento que tem como fundamento a escuta da outra cena.

1934. Freud recolhe das cinzas amontoadas nas fogueiras de Berlim as letras de seus livros e com elas começa a escrever "Moisés e o monoteísmo" (Freud, [1939] 1976), obra publicada em tempos diferentes: os dois primeiros capítulos em Viena, 1937, aproximadamente um ano antes do início da Segunda Guerra; e o terceiro publicado sob os céus de Londres, em 1938. Para cada publicação um prefácio que introduz o leitor a este hipertexto cuja escrita não se presta a captura. Como um enigma, Moisés está aberto a vários níveis de entendimento. O leitor tem nas mãos uma obra-testamento da metapsicologia dividida entre o estudo de 
diferentes mecanismos psíquicos de defesa - Verneinung, negação e Verleugnung, recusa da realidade ${ }^{1}$ - o questionamento da concepção da idéia de identidade versus o discurso diferencial das marcas identificatórias e a reescrita do mito do assassinato do pai construído em 1912. Já o analista interessado em refletir sobre os destinos da descoberta freudiana na cultura encontra em uma das questóes que movem a escrita do texto - como manter a transmissão da psicanálise em contextos históricos dominados pelas forças intolerantes e mortíferas da ideologia? uma fonte de pesquisa. Sobre o efeito destas forças no plano da História, o texto ganha força quando trabalhado no sentido de apreender o pensamento freudiano sobre a intolerância ao outro.

Com a ascensão do anti-semitismo, Freud retoma o tema da violência que o levou, durante a Primeira Guerra Mundial, a denunciar a explosão de barbárie na civilização moderna. Neste sentido, "Moisés e o monoteísmo" (Freud, [1939] 1976) pode ser considerado como uma resposta de Freud à questão que ele próprio endereçou em carta datada de 30.4.1934 a Zweig.

O ponto de partida do meu trabalho é um assunto que lhe é familiar. [...] Diante de novas perseguiçôes, torno a me perguntar como foi que nasceu o judeu e qual é o motivo pelo qual ele atrai para si este ódio inextinguível. Rapidamente encontrei uma fórmula. O judeu foi criado por Moisés, e meu livro ganhou o título O homem Moisés, um romance histórico (com muito mais direito que sua novela sobre Nietzsche) (Freud \& Zweig, [1968] 1974: 99).

Pergunta e resposta chaves à leitura de "Moisés e o monoteísmo" (Freud, [1939] 1976): entre as letras dos textos da tradição hebraica, de onde extrai os traços da singularidade judaica, o autor se ocupa em refletir profundamente sobre a estrutura "religiosa" de um Estado laico que, sob o signo do ódio, fomentava um estado de tolerância máxima entre os homens tidos como idênticos e de intolerância absoluta ao outro.

Sob a mira do nazismo e assolado pelo pânico de que a severa atmosfera católica de Viena pudesse acirrar resistências contra a psicanálise, Freud deixou Moisés na gaveta por quatro longos anos. Além dessas resistências externas, algumas "resistências internas" contribuíam para a quarentena deste texto que traz a marca da ligação entre a história do autor e a história da psicanálise ${ }^{2}$. Logo no início, o autor confessa que, apesar de pertencer ao povo judeu, fato que torna sua tarefa mais difícil ainda, contestará a origem do homem que este povo celebra como o maior de seus filhos (Freud, [1939] 1976). Enunciado traumático. Desidentificar o profeta maior que criou e fundou a religião mosaica, torná-lo um 
outro, um egípcio, à primeira vista parece ser uma tese bastante insólita. Mas, do ponto de vista da história da cultura, ela já havia sido defendida por alguns mestres do Iluminismo, que fizeram de Moisés um Aufklärer (Le Rider, 1992). Entre os historiadores de seu tempo, Freud encontrou nos escritos de Ed Meyer um apoio inconteste. A condição de estrangeiro de Moisés também não é estranha ao próprio corpo doutrinário do judaísmo: no Zohar, ele aparece como um egípcio, um homem que fazia revelar o infinito pela escritura diferencial do tetragrama IHVH.

Diferentes foram os caminhos percorridos por Freud para dar fundamentos à construção de Moisés. Em seu trabalho de leitura-escrita, buscou provas fora do texto bíblico, nas marcas denegadas pela tradição, como, por exemplo, a inexistência da palavra Moisés na etimologia do hebraico. O nome corresponde a mose, termo que se traduz como "menino", além de ser uma partícula componente do nome de reis egípcios. Mas este achado não contradiz a lenda da adoção de Moisés por uma princesa egípcia e, portanto, não é prova suficiente de sua hipótese. Um segundo argumento, com base na tese de Otto Rank (1909) de uma estrutura narrativa comum entre os mais diversos mitos de nascimento do herói, fornece a pista.

Ao contrário do mito de Édipo e de muitos outros mitos, a história bíblica difere em aspectos básicos: Moisés não é filho legítimo de pais ricos; seu nascimento não foi anunciado pelo oráculo como uma ameaça ao pai; quando criança não é salvo, pelos animais ou pessoas de condições mais baixas, da rejeição dos pais, e quando adolescente não triunfa sobre o pai. Freud insiste em que estas diferenças podem ser atribuídas às características especiais da história do herói. As duas famílias de Moisés (a aristocrática e a humilde) seriam apenas reflexos da família do menino, sendo possível verificar que a primeira pela qual a criança é abandonada era inventada e a segunda, pela qual ele foi recebido, a verdadeira. No entanto, há uma outra diferença importante que não pode permanecer desapercebida: ao contrário dos heróis que se elevam muito acima de suas origens humildes, a vida de Moisés começou por sua descida de uma posição proeminente para igualar-se ao nível dos filhos de Israel.

Todas as diferenças do texto bíblico por relação ao mito do herói impõem a Freud, conforme as observações de Brigitte Lemérer (1999), uma solução que não é em si mesma mais que uma nova hipótese. Se Moisés fosse egípcio, título do segundo ensaio, apresenta uma série de contradições - a) dois fundadores da religião (Moisés o egípcio e Moisés o medianita); b) dois deuses (Aton e Yavé) e duas fundações da religião (Egito e Cadés) - com as quais Freud determinará a exceção que confirma a regra e, com isso, a condição de estrangeiro do Profeta: Moisés, o egípcio, inventa o judeu; então, todo judeu é um egípcio, isto é, está para além da 
raça e do sangue: estrangeiro de si mesmo. Figura crítica, Moisés, o egípcio é signo da impossibilidade de significação única, fixa e imutável da identidade.

Com base no princípio freudiano da não-diferença entre a psicologia social e a individual - "o indivíduo é simultaneamente o social” (Freud, [1921] 1976: 67) -, pode-se afirmar que "Moisés e monoteísmo" (Freud, [1939] 1976) ilumina, com cores fortes, a questão da singularidade do povo judeu que, na condição de estrangeiro (Fuks, 2000), representava uma ameaça à concretização do projeto nazista de identidade da raça. E aqui o conceito de judeidade - o modo como alguém se afirma judeu subjetivamente, mesmo quando afastado inteiramente da religião - ilumina, com cores fortes, a desapropriação freudiana da figura maior do judaísmo. Se judeidade significa, como faz notar Derrida (1995), uma maneira de tornar-se outro, então o Moisés freudiano se inscreve como oposição absoluta à ideologia racista do nazismo que fortaleceu fundamentos ao totalitarismo alemão. A judeidade é o antítipo, por excelência, do mito ariano da raça pura, usado como instrumento de identificação mimética a uma identidade linear, concreta e sem rupturas - conforme a leitura de Philippe Lacoue-Labarthe e Jean-Luc Nancy em O mito nazista (2002). A figura do "outro" a ser excluído encontrou no judeu a negatividade mesma deste projeto: a judeidade é expressão de uma errância milenar, de uma alteridade multiplicada, fragmentada em estilhaços pelos cortes significantes do que ela própria esconde.

"Moisés e o monoteísmo" (Freud, [1939] 1976) é fruto desta trajetória: um texto marcado pela experiência intelectual de um pensador do exílio, estrangeiro de si mesmo. O herói consagra seu destino ao imperativo ético de assegurar a transmissão do saber recebido; um herói que Freud perseguiu "como alma penada” (Lemérer, 1999: 52), quando os nazistas começaram a "destruir o nó entre nome e carne, entre verbo e corpo, para fazer da filiação puro vínculo de sangue" (Rabinovitch, 2000: 41). Para o nazismo, a raça, o povo, sendo ligado ao sangue e ao solo de onde ele jorra, determina a identidade (Lacoue-Labarthe \& Nancy, 2002). A resposta freudiana a esta visão de mundo que de certo modo operava um corte na tradição de busca ou reconhecimento de identidade foi fundamentar uma concepção de transmissão descontínua de ruptura e reversões entre o passado e o futuro. Inspirado nos versos de Goethe, "Aquilo que herdaste de teus pais, conquista-o para fazê-lo teu" (Goethe, Fausto, parte 1, cena 1, citado por Freud, [1912] 1976: 159), Freud recorre à tradição do monoteísmo, não para defender as idéias do judaísmo, mas para usá-lo como exemplo de que um sistema de filiação se insere, inevitavelmente, na ordem de origem da não-origem, do estrangeiro. $\mathrm{O}$ verbo conquistar do adágio do escritor dá o tom a Freud: a transmissibilidade do "hereditário" inclui a transmissão de um desconhecido que, fora da ordem da 
natureza, só se transmite pela operação de retorno a um ponto de origem que, paradoxalmente, dará origem a uma outra montagem do legado da geração antecedente. Para além da biologia e da geografia, o sistema de filiação é puro efeito da temporalidade nachträglichkeit, que determina a subjetivação de marcas que não podem ser significadas.

A hipótese sobre a origem estrangeira do monoteísmo judaico serve de base para que Freud desenvolva suas reflexões sobre a intolerância à alteridade como expressão da vontade de assegurar a coesão do idêntico a Si, destruidor de tudo o que se opõe à proeminência absoluta do outro. Compreender este ódio ao outro através da metáfora do Judeu, o ancestral unheimlich das massas, exigiu de Freud o uso do conceito de narcisismo das pequenas diferenças. Perscrutando as diferenças entre alguns povos e o povo errante, encontra que a intolerância das massas se exterioriza com muito mais intensidade frente às pequenas diferenças que caracterizam os judeus do que às fundamentais (Freud, [1939] 1976). A segregação e o racismo situam-se, portanto, na dimensão agressiva do sujeito frente a uma pequena diferença, que provoca angústia. Diferença ex-tima: o horror ao que é mais íntimo e que, tomado pelo eu como um objeto externo, constitui-se em objeto do ódio na segregação e no extermínio. No contexto dessa interpretação, o discurso do Führer alemão é exemplar, pois permite perceber com clareza que o judeu era, a um só tempo, o que ele guardava de mais íntimo e o que lhe era mais estranho: um estranho estrangeiro. "O judeu habita em nós; porém é mais fácil combatê-lo sob sua forma corporal do que sob a forma de um demônio invisível” (Fuks, 2000: 92), confidenciou certa vez Adolph Hitler a Herman Rauching.

A História mostrou o poder da lógica deste discurso: mobilizou a massa que, capturada pelas malhas fascinantes dos jogos identificatórios com o seu líder, era induzida a dirigir hostilidade e ódio ao judeu (Freud, [1930] 1976). Uma verdadeira religiāo do Estado revigorou a intolerância da fé da Idade Média: o antisemitismo atinge o clímax quando Hitler se tornou uma espécie de "líder divino" que, amparado pela fidelidade incondicional das comunidades fraternas, assenta o programa político de reduzir o outro a um corpo indistinto sob o império da pulsão de destruição. Este destino pulsional do político, legitimado pela negação da existência do outro identificado a um verme ou a um vírus portador de infecção, dominou o totalitarismo alemão tal como hoje o conhecemos.

Resta ainda examinar as diferenças irredutíveis do judaísmo que serviram de base para identificar os judeus como "inimigo objetivo" do Nacional-Socialismo, nos termos de Hannah Arendt (1979)³. Desde o final do século XIX, a imagem do pênis circunciso, considerado como alterado, danificado ou incompleto, esteve no centro da definição de judeu. Fantasias giravam em torno da idéia de que a 
circuncisão era um processo de feminização do varão judeu, deixando seu órgão sexual degenerado e altamente comprometido com as doenças sexualmente transmissíveis. Mas este pânico da feminização que atingia a cultura européia recaía, também, sobre uma outra figura de alteridade, a feminilidade. Em Mein Kampf, o horror à feminização tornou-se a retórica do programa político: "a mulher introduz o pecado no mundo, sendo, então, a principal causa da poluição do sangue nórdico”, escreveu Hitler (Le Rider, 1992: 292).

Já foi adiantado no início deste texto que a reflexão sobre a intolerância à mulher e ao judeu ocupa um lugar especial no pensamento psicanalítico. Freud estabeleceu uma homologia entre a impressão inquietante causada pelo sexo da mulher e a vivência sinistra do homem diante da circuncisão. Ambas provocam um horror determinado, o horror à castração. E quando, em psicanálise, fala-se em horror à castração está se falando sobre a angústia que a diferença causa. É esta angústia que, na perspectiva de "Moisés e o monoteísmo", Freud ([1939] 1976) afirma ser a raiz comum entre o antifeminismo e o anti-semitismo. Porque lembra a ausência ou a privação e desperta estranheza, a circuncisão faz com que, diante dela, o incircunciso se depare com a falência do ideal de uma virilidade sem perdas. Esta perda significava também uma ameaça ao projeto do Nacional-Socialismo, que via, na situação histórica da diáspora judaica, a vivência contínua e deslocamentos geográficos - um sinal extremamente negativo para a Nação.

Um outro traço provocador do ódio milenar ao judeu ressaltado por Freud é a convicção do povo sobre se dizer primogênito e eleito de Deus. Esta fantasia de eleição, induzida estrategicamente por Moisés, o egípcio, possui tal potência, diz Freud, que é compartilhada, embora pela via da inveja e do ciúme doentios, até pelos não-judeus. O discurso de Hitler não desmente esta percepção. "Não pode haver dois povos eleitos", pronuncia o Füher, "somos nós o povo de Deus" (Le Rider, 1992: 292). Eis a rivalidade imaginária que tomou corpo no nazismo, desde o seu início, quando da promulgação de leis de exclusão e confinamento do povo judeu nos guetos, até a Solução Final (o extermínio). Por outro lado, se o anti-semitismo clássico, tal qual ele existiu de grosso modo entre os séculos XI e XVII na Europa, manteve o "povo eleito" à distância, diante da idéia de adoção como fundamento do parentesco e da filiação embutida nesta fantasia judaica de eleição, o nazismo precisou impor uma solução radical - o extermínio -, na medida em que, como vimos, sustentava o sangue e o solo como originários da identidade.

Finalmente, Freud argumenta que, entre as diferenças que tornaram o judeu um eterno estrangeiro do outro, existem alguns traços inscritos na própria formação da alteridade da religião mosaica que a desqualificaram sumariamente como 
religião universal. Tendo como referência o mito psicanalítico da origem da cultura - o mito do pai gozador que por conta de sua morte (infligida pelos filhos) possibilitou a emergência da ordem cultural e regulou o gozo -, Freud se dá conta de que a falta de representação do assassinato do pai e a recusa dos judeus de conferir à religiāo a função de produzir ilusões conciliatórias sobre a vida e a morte tornam o judaísmo uma religião inquietante e pouco tolerável (Freud, 1982). Trata-se de uma falta que alimenta a intolerância e os ressentimentos contra os judeus por parte daqueles que se aliviaram do trauma original - a culpa resultante do assassinato - ao oferecer o filho de Deus como vítima expiatória. A questão sobre a ausência de representação do assassinato, sobre a qual Freud confessa ter lançado pouca luz, foi deixada em aberto; embora ele tenha feito esforços para responder; apoiado, de um lado, nas pesquisas do historiador e exegeta Sellin, que encontrou na passagem bíblica de Oséas elementos para interpretar o assassinato de Moisés, por outro lado, o próprio trabalho de leitura à letra do livro do Êxodo, leva Freud a construir o terceiro mito do assassinato do pai.

Não se pode negar que a intenção de estabelecer um real anterior e exterior ao psiquismo exige de Freud, em seu trabalho de escrita, trabalhar com os mecanismos de recalque, repressão e denegação (Balmès, 1999). É esta fidelidade ao que não se mede pelo tempo ou pela realidade dos fatos que assegura a "Moisés e o monoteísmo" (Freud, [1939] 1976) a condição de texto metapsicológico. Neste sentido, pode-se sustentar, sem arbitrariedade, que para o criador da psicanálise não era necessário que a morte de Moisés fosse absolutamente "verdadeira”; o que o teria levado, apesar de reconhecer a fragilidade da hipótese de Sellin, a tomá-la como correta.

Não obstante, sabe-se que Freud introduziu na psicanálise um modo de ler a história muito diferente da historiografia ocidental. A leitura que faz sobre o texto bíblico é construção de uma "verdade histórica" que, à diferença da verdade material, é pensamento ou crença que inclui o sensível na abstração que se faz. É certo que o estatuto da noção de "verdade histórica" não é muito claro no texto freudiano, mas não levar em conta a diferença entre "verdade histórica" e verdade material equivoca muitos historiadores e filósofos que se detêm sobre Moisés (Castro, 1999). Mais problemática ainda é a freqüência do "esquecimento" da noção por parte de psicanalistas que insistem em invalidar a construção freudiana, uma ficção teórica que legitima conceitos com os quais Freud opera ${ }^{4}$. Nem verdade material, nem tampouco verdade reprimida: a construção do mito de Moisés e de seu assassinato, conforme Freud indica expressamente no texto, é "verdade histórica".

Sustentar que o assassinato de Moisés é uma questão de texto e não de realidade nos traz de volta à indagação de Freud sobre a singularidade do povo judeu ao não admitir ter matado o Pai. Quais as conseqüências disto frente ao poder das 
organizações que encenam diretamente o modelo da horda, do assassinato e do amor à figura do Pai?

Para abreviar, voltarei ao terceiro ensaio, ao ponto de partida da reflexão freudiana sobre o progresso na "vida do espírito" (Geistigkeit). Freud nos fala que este progresso se dá não como processo, mas como corte do registro sensorial para o do espiritual e do pensamento. Na religião do homem Moisés, a lei de proibição da imagem de Deus traz como conseqüência, desde a perspectiva psicanalítica, a espiritualidade como efeito da renúncia e da repressão pulsional.

Convidemos o pensamento de Lacan ([1959-1960] 1998) para iluminar esta passagem: Moisés, o egípcio, inventa, segundo suas observaçōes no ensaio "A morte de Deus", a concepção de um Deus cuja presença define-se por uma ausência radical e absoluta e uma ética de superação das idolatrias. Uma ética iconoclasta. IHVH, o tetragrama impronunciável que designa o Nome, é verbo - "Eu serei o que serei" -, uma promessa que não se cumpre e que se apresenta sempre no futuro. Eis o paradoxo da religião de Moisés, o estrangeiro: longe de fornecer resposta apenas ao desamparo, reenvia o sujeito ao eco de sua própria voz. Assim explica-se, de resto, por que Lacan propõe que a especificidade de IHVH é designar-se como essencialmente Outro; o que lhe permitiu criar em 1973 o seguinte aforismo: "A verdadeira fórmula do ateísmo não é que Deus está morto; a verdadeira fórmula do ateísmo é que Deus é inconsciente" (Lacan, [1963-1964] 1973: 32-33). Desta afirmativa Lacan situa o pai como o significante que garante a outridade, isto é, como a lei que garante a existência do outro.

Numa outra ponta, o pensamento de Emanuel Lévinas (1994) presta-se também à escuta desta diferença inextricável que é a idéia mosaica da irrepresentabilidade: a idéia de Deus para além do ser é o ateísmo mais vigilante senão o mais desesperado, a própria inscrição do nome de Deus - o tetragrama impronunciável e indizível, IHVH, seria a própria inscrição originária da diferença. Este Deus que, como já se disse, se apresenta no futuro - "Eu serei o que serei" - e não admite imagem fez os homens à sua própria imagem e semelhança. Esta antinomia - identificação à ausência de imagem - estabelece na tradição que o homem é também irredutível a qualquer representação fixa e imutável (Levítico, 19.2). Daí que aquilo que o filósofo vem a chamar de lei é o que se funda no ser-antes-domesmo, é a anterioridade da ética do outro em relação à concepção de identidade (Lévinas, 1997).

Os pensamentos de Lacan e de Lévinas nos convidam a extrair do trabalho de Freud uma avaliação sobre o modo como o discurso nazista operou sobre a formação da alteridade do povo judeu para promover a intolerância e o arbítrio ao outro. Para Hitler era essencial revelar: 
que o Judeu não é simplesmente uma raça ruim, um tipo defeituoso: ele é o antítipo, o bastardo por excelência. O Judeu não possui forma ou figura da alma (Seelengestalt). [...] O Judeu não é o antípoda do germânico, mas sua contradição, o que sem dúvida quer dizer que não se trata de um tipo oposto, mas da ausência mesmo de tipo (Lacoue-Labarthe \& Nancy, 2002: 53).

Ou seja, a proibição mosaica de construir imagens causa assombramento, do mesmo modo que o corpo do judeu. O Judeu é ausência de imagem, sendo, portanto, uma ameaça real à obsessão de figuração que alimentava o sonho alemão de erigir uma figura e de produzir sob este modelo um tipo da humanidade (Lacoue-Labarthe \& Nancy, 2002: 80). As referências que Freud faz ao longo dos três ensaios de Moisés, a idéia de pensar uma origem na não-origem, a crítica sistemática a qualquer concepção biológica da transmissão e o destaque que dá ao registro da linguagem em oposição ao da imagem revelam que tanto a ética judaica como a tradição religiosa assombravam o Ocidente, em particular os nazistas, que alimentavam ódios profundos e assassinos contra aqueles que inventaram a presença da Ausência.

Ao convocar as letras da Escritura à tarefa de pensar o presente - a intolerância mortífera do Estado Alemão -, Freud está totalmente implicado no acontecimento da interpretação. Em seu êxodo renovado do Egito/Viena à Palestina/Londres responde produtivamente à dor e ao luto trazidos pelo evento nazista. Renova a teoria, constrói texto, convoca palavras, reinscreve traços, corta letras, dá corpo aos brancos de um pergaminho de tempos imemoriais e ressignifica genialmente o Livro dos livros, impulsionado a dominar a pulsão de morte lá onde a palavra mata a Coisa. Entre o real da segregação e o fardo ético da sobrevivência, serve-se da escrita para contar a experiência do que é ocupar este lugar estranho-familiar de excluído, atravessando as idéias e pensamentos como os nômades atravessam o deserto. E talvez seja deste gesto, que em última instância significou tornar a psicanálise mais forte que a destruição, e de seu desejo expresso de no exílio pedir licença para dar continuidade à transmissão de um método e teoria voltado à escuta do Outro que seja possível esboçar uma definição psicanalítica de tolerância, sem abrir mão do conceito psicanalítico de "narcisismo das pequenas diferenças"; o que significa admitir, como já se disse, a existência inextinguível do conflito com seu oposto, a intolerância.

Podemos, então, ousar definir psicanaliticamente a tolerância como o ato de: a) admitir nossa própria intolerância frente ao estranho; b) aceitar-se estrangeiro para si mesmo e pagar o preço da própria singularidade; c) saber ocupar o lugar de estrangeiro para o outro que nos vê como encarnação da ameaça de morte 
e como portador da mais radical ajuda; ou seja, encarnar o Nebenmench freudiano; d) reconhecer e acolher o inesperado, o de fora, o estrangeiro, o que escapa ao espelho, o para além do idêntico, sobretudo sem pretensões ao proselitismo; e) saber que a tolerância diante do intolerável - o assassinato do outro - termina sempre em catástrofe (Fuks, 2006).

É neste ponto que a atualidade de "Moisés e o monoteísmo" (Freud, [1939] 1976) se faz exemplar. De um lado, o texto oferece ferramentas à psicanálise e às outras disciplinas para enfrentar os traumas da contemporaneidade que se seguem aos totalitarismos políticos do século XX, a saber: os três fundamentalismos, judaico, islâmico e cristão, cada qual avidamente disposto a exterminar o outro. Mas o texto também possui elementos que permitem uma leitura insólita dos fenômenos que, na pretensão de esgotar a intolerância, podem ser igualmente coniventes para com ela. $\mathrm{O}$ movimento que nasceu da necessidade de tolerância a todas as diferenças, o politicamente correto, contrário ao racismo e ao fascismo, está a ponto de se tornar uma nova modalidade de fundamentalismo (Eco, 2000). Uma alma pura de caráter ilibado, formatada por determinados comportamentos, e regras do uso de linguagem adequada a situaçóes inesperadas do cotidiano encerram o sujeito numa rede ritualística e mimética, capaz de torná-lo igualmente intolerante para com o outro que não se submete aos ditames do politicamente correto. Estas são algumas das liçóes que podemos extrair do pensamento freudiano sobre a intolerância.

\section{REFERÊNCIAS BIBLIOGRÁFICAS}

Arendt, H. (1979). As origens do totalitarismo: anti-semitismo, instrumento de poder. Rio de Janeiro: Editora Documentário.

Balmès, F. (1999). El nombre, la ley, la voz. Freud y Moisés: escrituras del padre 2. Barcelona: Ediciones del Serbal.

Castro, R. (1999). Notas sobre el Ruach o Geist y el hombre Moisés. Espectros Psicoanálisis, 3, 60-94.

Derrida, J. (1995). Mal d'archive, une impression freudienne. Paris: Galilée.

Eco, U. (2000). Definições léxicas. Em Barret-Ducrocq, F. (Org.). A intolerância (pp. 1619). Rio de Janeiro: BCD União de Editoras.

Freud, S. (1912). Tóten y tabú. Obras completas, v. XIII. Buenos Aires: Amorrortu Editores, 1976.

. (1918). Tabú de la virginidad. Obras completas, v. XI. Buenos Aires: Amorrortu Editores, 1976. 
. (1921). Psicología de las masas y análisis del yo. Obras completas, v. XVIII. Buenos Aires: Amorrortu Editores, 1976.

. (1925). A negativa. Obras completas, ESB, v. XIX. Rio de Janeiro: Imago, 1969. - (1930). El malestar en la cultura. Obras completas, v. XXI. Buenos Aires: Amorrortu Editores, 1976.

- (1933). ¿Por qué la guerra? Obras completas, v. XXII. Buenos Aires: Amorrortu Editores, 1976.

- (1939). Moisés y la religión monoteísta. Obras completas, v. XXIII. Buenos Aires: Amorrortu Editores, 1976.

. (1982). Death and us. Em Ostow, M. Judaism and psychoanalysis (pp. 4-22).

New York: Ktav.

Freud, S. \& Zweig, A. (1968). Correspondencia Freud-Zweig. Buenos Aires: Garancia, 1974.

Fuks, B. B. (2000). Freud e a judeidade, a vocação do exílio. Rio de Janeiro: Zahar.

- (2006). Moisés e o monoteísmo: um estudo sobre a intolerância. Trabalho apresentado no I Simpósio Sobre Intolerância. Laboratório de Estudos sobre a Intolerância, USP, São Paulo, SP.

Lacan, J. (1959-1960). O Seminário, livro 7, A ética da psicanálise. Rio de Janeiro: Jorge Zahar, 1998.

. (1963-1964). O Seminário, livro 11, Os quatro conceitos fundamentais da psicanálise. Rio de Janeiro: Jorge Zahar, 1973.

Lacoue-Labarthe, P. \& Nancy, J.-L. (2002). O mito nazista. São Paulo: Iluminuras.

Lalande, A. (1993). Vocabulário técnico e crítico da filosofia. São Paulo: Martins Fontes.

Laplanche, J. \& Pontalis, J. B. (1970). Vocabulário de psicanálise. Santos: Martins Fontes.

Lévinas, E. (1994). Dios, la muerte y el tiempo. Madri: Colección Teorema.

- (1997). Entre nós: ensaios sobre a alteridade. Petrópolis: Vozes.

Le Rider, J. (1992). A modernidade vienense e as crises de identidade. Rio de Janeiro: Civilização Brasileira.

Lemérer, B. (1999). Los dos Moisés de Freud (1914, 1938). Freud y Moisés: escrituras del padre 1. Barcelona: Ediciones del Serbal.

Prado de Oliveira, L. E. (2005). Cuestiones acerca de la muerte del padre: algunos crímenes ejemplares. Tempo Psicanalítico, 37, 139-152.

Rabinovitch, S. (2000). Escrituras del asesinato. Freudy Moisés: escrituras del padre 3. Barcelona: Ediciones del Serbal.

Rank, O. (1909). El mito del nacimiento del héroe. Buenos Aires: Paidós.

Wismann, H. (2000). A tolerância na filosofia alemã. Em Barret-Ducrocq, F. (Org.). A intolerância (pp. 98-101). Rio de Janeiro: BCD União de Editoras. 


\section{NoTAS}

1 Laplanche e Pontalis (1970) propõem traduzir Verneinung por (de)negação, dada a ambigüidade entre "negação-denegação" que aparece no texto A negativa (1925). Costuma-se também traduzir Verleugnung por renegação ou desmentido, para deixar caracterizada a dupla operação deste mecanismo: reconhecimento e recusa - da realidade.

2 Ver sobre isto o livro Los dos Moisés de Freud $(1914,1939)$ de Brigitte Lémerer (1999). A autora mostra como as resistências internas de Freud à publicação de Moisés foram ainda mais fortes que as resistências externas. Elas estavam associadas à dificuldade do autor em transmitir, isto é, em levar adiante as teses que sustentaram a escrita do texto.

3 O conceito de "inimigo objetivo", desenvolvido por Arendt (1979) em As origens do totalitarismo: anti-semitismo, instrumento de poder, se aproxima da concepção de "narcisismo das pequenas diferenças", ainda que dele se diferencie por razões de enfoque.

${ }^{4} \mathrm{O}$ artigo de Luiz Eduardo Prado de Oliveira (2005), Cuestiones acerca de la muerte del padre: algunos crímenes ejemplares, é um exemplo da resistência dos analistas a reconhecer o valor da aplicação da noção de "verdade histórica" no texto de Moisés. A confusão entre verdade material e verdade histórica feita pelo autor redobra a confusão entre dois conceitos psicanalíticos: repressão e desmentido. Ao insistir na busca da verdade material do texto bíblico, o autor distancia-se não apenas do propósito da ficção freudiana, como de toda a técnica de construção em análise defendida por Freud. Procede como um historiador que desconhece a prática psicanalítica de leitura de texto escrito. Enfim, Prado Oliveira ignora que a noção de verdade histórica ratifica o estatuto de real do texto bíblico na construção de Moisés.

Recebido em 26 de abril de 2007 Aceito para publicação em 16 de julho de 2007 